\title{
Financial Literacy in Millenials Generation in Indonesia
}

\author{
Delia Anindita Prashella*, Farah Margaretha Leon \\ Faculty of Economics and Business \\ Universitas Trisakti \\ Jakarta, Indonesia \\ *aprashella@gmail.com
}

\begin{abstract}
This study aims to examine financial literacy in millennials in Indonesia. The dependent variable used in this study is a propensity for indebtness. The independent variable used is financial literacy as measured by financial behaviour, financial attitude and financial knowledge. Variables that act as independent dependent variables are materialism and compulsive buying. The sample of this study used 535 respondents who used a purposive sampling method. The data analysis model used is structural equation modelling (SEM). The results of this study indicate that financial literacy has a negative impact on propensity to indebtedness, materialism has a positive impact on compulsive buying, compulsive buying has a positive impact on propensity to indebtedness, materialism has a positive impact on compulsive buying, financial literacy has a negative impact on materialism and literacy finance has a positive impact on compulsive buying. Therefore, raising the level of financial literacy from an early age on individuals through financial education can lead a prosperous life and can be effective in minimizing negative behaviours such as compulsive buying, materialism, and propensity to indebtness. This research is unique and innovative in so far as measuring the direct impact of financial literacy is very influential on other factors such as compulsive buying, materialism, and propensity to indebtedness which is that financial literacy has a far more significant impact than shown by other academic studies, especially on the millennial generation in Indonesia.
\end{abstract}

Keywords—compulsive buying, financial literacy, materialism, a propensity to indebtedness

\section{INTRODUCTION}

Consumers must face complex financial decisions at an early age in the current economic environment, so they are not easily affected by the global financial crisis. The National Economy will not be easily affected by the global financial crisis if people understand the financial system. Misunderstanding in managing finances caused many people to suffer financial losses, as a result of excessive spending and consumption, unwise use of credit cards, and calculating the difference between consumer credit and bank loans. In Indonesia, the level of financial literacy is still below that of other ASEAN countries, even though Indonesia has the largest population in Southeast Asia. The level of financial literacy in
Indonesia can be said to be low, because only $21.7 \%$ compared to the Philippines which is above $30 \%$ and in Malaysia around $60 \%-70 \%$. The low level of financial literacy can be caused by the lack of balance between the level of public awareness of managing their finances and this financial literacy will adversely affect the prosperity of the people [1].

Financial literacy aims to increase and expand knowledge of understanding about managing finances so as to create prosperity and the realization of a desire to invest. The level of financial literacy can be seen from how well the individual is able to use, determine the funds for spending, manage life risks, manage their assets, and prepare for the security of financial resources in the future [2]. One way to increase understanding of financial literacy besides taking part in financial education and investing is to use current financial technology facilities [3]. Financial technology companies have big opportunities in Indonesia because technology is very inherent in Indonesian society today. Based on data from the 2016 Indonesia Fintech Report, it is stated that $18.86 \%$ of Indonesian people have utilized the services of financial technology and the benefits of financial technology itself, one of which is that people will be more familiar with digital financial products [4]. The community itself can choose financial products according to their wants and needs that can help financial management and to invest that can help all people including. The level of financial literacy will vary according to demographic characteristics, one of which is age which greatly determines people's point of view of something, including the millennial generation. Therefore, an individual may have financial knowledge, but to be considered capable of financial processing must have the abilities and beliefs needed to be able to apply financial knowledge to every decision that will be made [5] and financial literacy can benefit individuals and family, because if individuals with a high level of financial knowledge, then they will tend to be able to manage their finances better [6]

Individuals with low levels of financial literacy tend to be more propensity to independebtness which refers to it being easier to make loans and will continue to do so without thinking of the limits [7]. In addition, those who are more 
consumptive at a young age because of the low level of financial literacy can hamper the wealth of the individual in the future. Specifically, materialism behaviour influences compulsive buying behaviour, because consumers who do not have the ability to control their desires and purchases will tend to behave extravagantly. On the other hand, compulsive buying also has a direct impact on propensity to indebtness. This happens when consumers tend to prefer to behave consumptively and continuously without regard to their financial condition, so they will be easier to buy by way of debt in the form of credit cards or bank loans or loans to other individuals which will lead to financial problems [8], even compulsive buying can cause serious financial debt [9]. Materialism can influence compulsive buying behaviour which refers to someone with very materialistic values who believe that the acquisition of material goods is the primary life goal, the main indicator of success and the key to happiness [9].

In addition, financial literacy can reduce or even prevent loan problems, because prevention is far more effective than fixing it later. With financial literacy, it is expected that individuals can design their finances as well as possible and can reduce the level of delinquency on loans [8]. This study will examine the impact of financial literacy on financial behaviour on millennial generation in Indonesia. The study was conducted with variables of financial literacy, propensity to indebtness, materialism and compulsive buying conducted by millennials in Indonesia. This research is innovative in so far as measuring the direct impact of financial literacy is very influential on other factors such as compulsive buying, materialism and propensity to indebtness which is that financial literacy has a far more significant impact than shown by other academic studies, especially on millennial generation in Indonesia. It is hoped that the millennial generation will be able to process or control its finances properly so as not to lose money in the future.

\section{LITERATURE REVIEW}

Research shows that there is a positive influence between poor financial literacy and propensity to indebtness[10]. The lack of financial literacy was found to result in higher costs, bad loans and loan arrears. Previous studies analysing the negative relationship between financial literacy and consumer credit, also found evidence that individuals who obtain loans at higher costs are those who have lower levels of financial education and also those who have more propensity to indebtness [8]. Other research also shows that low individual financial literacy is negatively related to propensity to indebtness which means that individuals easily make the decision to make credit in Disney and Gathergood [11].

H1: There is an impact between financial literacy on propensity to indebtness

Materialism is a major factor causing propensity to indebtness [9]. In those who have a materialistic attitude have an attitude that cannot control themselves against the use of credit and are more susceptible to propensity to indebtness states that individuals with a higher level of materialism have a positive relationship with propensity to indebtness, i.e. the higher the level of materialism of eating will increasingly high also propensity to indebtness [8]. Consumers who are very materialistic are more likely to have a wasteful nature that spends more money and is more easily indebted which causes a positive effect on propensity to indebtness, because the higher the attitude of materialism in individuals, the higher the level of propensity to indebtness [12]

$\mathrm{H} 2$ : There is an impact between materialism on propensity to indebtness

Excessive product purchases for individuals and unnecessary purchases cause budget constraints that will lead to proportions to indebtness which if not resolved will harm the individual himself. High compulsive buying will have a positive impact on propensity to indebtness which means individuals who are more consumptive and high levels of depression and stresses that the higher compulsive buying of individuals will lead a person towards propensity to indebtness [8]. Individuals who experience the character of compulsive buying have an irresistible desire, a repeated and strong urge to continue to buy goods. These goods are often not useful or even not used because of the many product offerings and prices that if it cannot be controlled will increase the level of propensity to indebtness [7]. For individuals who have a soul as compulsive buying will have a positive impact with propensity to indebtness because of the use of irrational loan products [13]

H3: There is an impact between compulsive buying on propensity to indebtness

Materialism can be associated with compulsive buying in which individuals lose control of the urge to want to buy products continuously and excessively even though there will be adverse risks. Materialism is positively correlated with compulsive buying, which shows that the more the individual has a high level of materialism, the higher the possibility for the individual to become compulsive buying [14]. A high frequency of compulsive buying is found in individuals with strong materialism values [8]. Individuals who have the attitude of materialism have a chronic tendency to spend outside of individual needs that lead to the pleasure and satisfaction of these individuals which makes materialism a positive effect on compulsive buying [13].

H4: There is an impact between materialism on compulsive buying

Materialism attitude in individuals is required to negate the values of materialism, financial education is considered to influence the prevention of materialism because in the knowledge of financial literacy are taught various ways for how to manage finances well and get prosperity in the future. With financial literacy, it is expected that individuals can make financial budgets for their future as well as possible, which means that a high understanding of financial literacy will have a negative impact on materialism [8]. Lack of awareness of the importance of financial literacy can foster an attitude of materialism aimed at showing off their status or for the individual to be happy without thinking about long-term financial effects [15]. Materialism's attitude encourages individuals not to think about or consider the consequences first, which occur due to lack of financial literacy. Therefore, researchers find that high knowledge about financial literacy will negatively impact the level of materialism in individuals [9].

H5: There is an impact between financial literacy on materialism 
Knowledge of financial literacy obtained through education in formal and informal education and suggested as a way to reduce compulsive buying and individuals who are included as compulsive buying may not apply financial literacy practices. Those who spend excess money tend to have a low level of knowledge in knowledge about financial literacy. In particular, financial literacy learning and training can have a negative impact on compulsive buying for individuals [8]. If individuals do not have a plan or are not aware of the importance of saving in the future, including individuals who have a compulsive buying attitude that will quickly spend their income when they have received it [2]. In addition to the lack of knowledge about financial literacy that has a negative impact, many individuals who cannot control themselves to not have a compulsive buying attitude because of the increasing development of technology that uses for promotion and sales through the internet and social media [16].

H6: There is an impact between financial literacy on compulsive buying

\section{METHODS}

The population in this study is the millennial generation in Indonesia who was born in 1981 to 2000 , which means the age group of 19-39 years which includes the productive age. The number of members of the population is not known clearly, because the number is very much, so this study took a sample. The sampling technique in this study uses a purposive sampling method that meets certain criteria, namely only individuals belonging to millennial generation and individuals who have done a type of loan that is often done, one of the sources coming from commercial banks, savings and loan cooperative banks, finance company's sales, pawnshop or friends and relatives (relatives). The questionnaire will be distributed online by distributing questionnaire links using Google forms.

Questionnaires were distributed as many as 795 questionnaires, but questionnaires that could only be used were 535 questionnaires because as many as 250 respondents had never used loans and 10 respondents were not included in the millennial generation. The analysis method used in this study is the Structural Equation Model (SEM) using the AMOS 24 program. SEM is a model that seeks to explain the relationship between variables that previously tested the validity and reliability. Measurements made to obtain the results of financial literacy respondents measured in 3 ways namely with financial attitude, financial behaviour and financial knowledge, then the propensity to indebtedness, materialism and compulsive buying variables with the Likert scale questionnaire methods.

\section{RESULTS AND DISCUSSION}

\section{A. Result}

The level of financial literacy in the Millennial generation in Indonesia is high, in the amount of 274 respondents with a percentage of $51.2 \%$, which includes moderate as many as 261 respondents with a percentage of $48.8 \%$ and none of which is low. The results of $\mathrm{H} 1$ from research that has been done show that there is a negative influence of financial literacy on propensity to indebtness as indicated by a p-value of 0.0000 .05 and with an estimated value of -0.268 means the results of this study indicate that there is a negative influence between financial literacy and consumer credit which means that individuals who obtain loans at higher costs are those who have a lower level of financial education and also those who have more propensity to support. The $\mathrm{H} 2$ results from the research that have been done show that there is a positive influence of materialism on propensity to indebtness which is indicated by the p-value of 0.03950 .05 and with an estimated value of 0.371 , it means that the results of this study state that people who have a materialistic attitude have an attitude that is not can control themselves against the use of credit and more susceptible to propensity to indebtness states that individuals with a higher level of materialism have a positive relationship with propensity to indebtness, i.e. the higher the level of eating materialism, the higher the propensity to indebtedness. The results of $\mathrm{H} 3$ from the research that have been done show that there is a positive influence of compulsive buying on propensity to indebtness as indicated by the p-value of 0.000 0.05 and with an estimated value of 0.863 means that the results of this study reveal that excessive product purchases for individuals and purchases that are not in need to cause budget constraints that will lead to propensity to indebtness which if not resolved will harm the individual himself and individuals who are more consumptive behaviour and high levels of depression and confirms that the higher compulsive buying of individuals will lead someone towards propensity to indebtedness. The results of $\mathrm{H} 4$ from the research that have been done show that there is a positive influence of materialism on compulsive buying as indicated by the p-value of $0,0000.05$ and with an estimated value of 2,771, meaning that the results of this study indicate that a high frequency of compulsive buying attitudes is found in individuals with materialism values the strong one. Individuals who have an attitude of materialism have a chronic tendency to spend outside individual needs which leads to individual pleasure and satisfaction. The results of $\mathrm{H} 5$ from the research that have been done show that there is a negative influence of financial literacy on materialism as indicated by the p-value of 0.00010 .05 and with an estimated value of -0.110 means the results of this study that with financial literacy, individuals can create financial budgets for the future they do their best which means that a high understanding of financial literacy will negatively impact materialism. The results of H6 from the research that have been done show that there is a positive influence of financial literacy on compulsive buying as indicated by a p-value of $0,0000.05$ and with an estimated value of 0.566 means that individuals with better financial literacy tend to use more financial products and services and also have positive behaviour in financial literacy. However, it is possible that financial knowledge alone is not enough to avoid compulsive buying behaviour.

TABLE I. RESUlT OF HyPOTHESIS TESTING

\begin{tabular}{|l|l|l|c|}
\hline \multicolumn{1}{|c|}{ Hypothesis } & Estimate & p-value & Decisions \\
\hline $\begin{array}{l}\text { H1: There is an impact between } \\
\text { financial literacy on propensity to } \\
\text { indebtness }\end{array}$ & -0.268 & 0.000 & H01 Rejected \\
\hline $\begin{array}{l}\text { H2: There is an impact between } \\
\text { materialism on propensity to } \\
\text { indebtness }\end{array}$ & 0.371 & 0.039 & H02 Rejected \\
\hline $\begin{array}{l}\text { H3: There is an impact between } \\
\text { compulsive buying on propensity } \\
\text { to indebtness }\end{array}$ & 0.863 & 0.000 & H03 Rejected \\
\hline $\begin{array}{l}\text { H4: There is an impact between } \\
\text { materialism on compulsive buying }\end{array}$ & 2.177 & 0.000 & H04 Rejected \\
\hline $\begin{array}{l}\text { H5: There is an impact between } \\
\text { financial literacy on materialism }\end{array}$ & -0.110 & 0.0001 & H05 Rejected \\
\hline $\begin{array}{l}\text { H6: There is an impact between } \\
\text { financial literacy on compulsive } \\
\text { buying }\end{array}$ & 0.566 & 0.000 & H06 Rejected \\
\hline
\end{tabular}




\section{CONCLUSION}

Based on the results of this study which aims to examine the effect of the dependent variable, namely propensity to indebtness with financial literacy as an independent variable measured by financial behaviour, financial attitude and financial knowledge as well as materialism and compulsive buying as the independent dependent variable on the millennial generation in Indonesia. So, it can be concluded that financial literacy has an influence on the propensity to indebtness, materialism, and compulsive buying. This means that the level of financial literacy greatly affects the lifestyle of the millennial generation because the higher level of financial literacy will reduce the negative things that will have a bad impact in the future. Therefore, educational institutions need to teach early on personal financial management skills with special courses and seminar activities so that not every individual does not lose money in the future and can live in prosperity and can effectively minimize negative behaviours such as compulsive buying, materialism.

\section{REFERENCES}

[1] A.A. Sjam, "Financial Literacy of College Students: Determinants and Implications," J Manaj Maranatha, vol. 15, pp. 1-12, 2015.

[2] F. Margaretha and S. May Sari, "Faktor Penentu Tingkat Literasi Keuangan Para Pengguna Kartu Kredit di Indonesia," J Akunt dan Investasi, vol. 16, pp. 132-144, 2016.

[3] S. Dwilita, D. SariPipit 1,2 Buana Sari, 2 Handriyani Dwilita. 2016; 917.

[4] P.B. Sari and H. Dwilita, "Prospek Financial Technology (FINTECH) di Sumatera Utara Dilihat Dari Sisi Literasi Keuangan, Inklusi Keuangan dan Kemiskinan,” Kajian Akuntansi, vol. 19, no. 1, pp. 09-18, 2018.
[5] S.J. Huston, "296 THE JOURNAL OF CONSUMER AFFAIRS Measuring Financial Literacy," J Consum Aff, vol. 44, pp. 296-316, 2010.

[6] S. Allgood and W.B. Walstad, "The effects of perceived and actual financial literacy on financial behaviors," Econ Inq, vol. 54, pp. 675697, 2016.

[7] A. Müller, J.E. Mitchell and M. De Zwaan, "Compulsive buying," Am J Addict, vol. 24, pp. 132-137, 2015.

[8] A.C.G. Potrich and K.M. Vieira, "Demystifying financial literacy: a behavioral perspective analysis," Manag Res Rev, vol. 41, pp. 10471068, 2018.

[9] R.B. Gardarsdóttir and H. Dittmar, "The relationship of materialism to debt and financial well-being: The case of Iceland's perceived prosperity," J Econ Psychol, vol. 33, pp. 471-481, 2012.

[10] D. French and D. McKillop, "Financial literacy and over-indebtedness in low-income households," Int Rev Financ Anal, vol. 48, pp. 1-11, 2016.

[11] R. Disney and J. Gathergood, "Financial literacy and consumer credit portfolios," J Bank Financ, vol. 37, pp. 2246-2254, 2013.

[12] Y.B. Limbu, B.A. Huhmann and B. Xu, "Are college students at greater risk of credit card abuse Age, gender, materialism and parental influence on consumer response to credit cards," J Financ Serv Mark, vol. 17, pp. 148-162, 2012.

[13] K.M. Palan, P.C. Morrow and A. Trapp, "Compulsive Buying Behavior in College Students: The Mediating Role of Credit Card Misuse," J Mark Theory Pract, vol. 19, pp. 81-96, 2011.

[14] N.A. Omar, R.A. Rahim and C.A.C. Wel, "Compulsive buying and credit card misuse among credit card holders: The roles of self-esteem, materialism, impulsive buying and budget constraint," Intang Cap, vol. 10, pp. 52-74, 2014.

[15] A.A. Arofah, Y. Purwaningsih and M. Indriayu M, "International Journal of Multicultural and Multireligious Understanding Financial Literacy," Materialism and Financial Behavior, pp. 370-378, 2018.

[16] O. Dikria and S.U. Mintarti, "Pengaruh Literasi Keuangan Dan Pengendalian Diri Terhadap Perilaku Konsumtif Mahasiswa Jurusan Ekonomi Pembangunan Fakultas Ekonomi Universitas Negeri Malang Angkatan 2013," J Pendidik Ekon, vol. 9, pp. 143-155, 2016. 